\title{
POTENSI KALIANDRA (Calliandra calothyrsus) DAN GAMAL (Gliricidia sp.) DI DAERAH ISTIMEWA YOGYAKARTA UNTUK PENGEMBANGAN PELET KAYU
}

\author{
Ahdiar Fikri Maulana ${ }^{1} *$, Singgih Utomo ${ }^{1}$, Puji Lestari ${ }^{1}$, Ridla Arifriana ${ }^{1}$, Denni \\ Susanto $^{1}$, Norma Aji Candra Dewi ${ }^{1}$, Adi Nugroho ${ }^{1}$, Eko Prasetyo ${ }^{1}$, Rachmadhila \\ Fajerin Pramono ${ }^{1}$, Wahyu Cahyo Saputro ${ }^{1}$, Dewi Sulistyowati ${ }^{2}$ \\ ${ }^{1}$ Program Studi Pengelolaan Hutan, Departemen Teknologi Hayati dan Veteriner, Sekolah \\ Vokasi, Universitas Gadjah Mada \\ ${ }^{2}$ Dinas Lingkungan Hidup dan Kehutanan, Daerah Istimewa Yogyakarta \\ E-Mail: ahdiar.f.maulana@ugm.ac.id
}

\begin{abstract}
ABSTRAK
Potensi Kaliandra (Calliandra calothyrsus) dan Gamal (Gliricidia sp.) di Daerah Istimewa Yogyakarta untuk Pengembangan Pelet Kayu. Negara-negara di dunia, khususnya Eropa, Jepang, Korea Selatan dan China, mulai beralih ke penggunaan energi terbarukan yaitu pelet kayu. Indonesia dengan iklim tropis, keanekaragaman jenis tanaman dan ketersediaan lahan untuk pengembangan sumber energi ini, berpeluang menjadi salah satu produsen utama pelet kayu, baik untuk memenuhi permintaan nasional atau internasional. Daerah Istimewa (DI) Yogyakarta merupakan salah satu provinsi di Indonesia yang memiliki hutan rakyat dan berpeluang untuk dikembangkan sebagai produsen pelet kayu. Penelitian ini bertujuan untuk memperoleh informasi awal tentang jenis tanaman kayu potensial di DI Yogyakarta. Pengambilan data dilakukan dengan studi pustaka dan survey kepada Kelompok Tani Hutan (KTH) di Kabupaten Bantul (22 $\mathrm{KTH})$, Gunungkidul (15 KTH), Kulonprogo (15 KTH) dan Sleman (19 KTH). Cabang dan ranting kering merupakan sumber bahan bakar kayu utama bagi KTH di DI Yogyakarta, tanpa melihat jenis tanamannya. Jenis kaliandra (Calliandra calothyrsus) dan gamal (Gliricidia sp.) sebagai jenis potensial untuk pelet kayu ditanam sebagai sumber hijauan makanan ternak, sumber nektar untuk peternakan lebah madu dan untuk konservasi tanah. Kedua jenis ini ditanam sebagai tanaman tepi di pinggir lahan, diantara tanaman pertanian dan atau tanaman berkayu, bukan sebagai tanaman utama. Jumlah yang ditanam sangat variatif berkisar antara 0 - 2000 pohon kaliandra/ha dan 0 - 3000 pohon gamal/ha. Berdasarkan hasil tersebut diketahui bahwa jenis potensial untuk produksi pelet kayu, kaliandra dan gamal sudah ditanam di 4 kabupaten tersebut. Namun penanaman kedua jenis tersebut perlu dikembangkan agar dapat mendukung produksi pelet kayu.
\end{abstract}

Kata kunci : DI Yogyakarta, gamal, kalindra, Kelompok Tani Hutan, pelet kayu.

\begin{abstract}
Potential of Kaliandra (Calliandra calothyrsus) and Gamal (Gliricidia sp.) In Yogyakarta Special Region for the Development of Wood Pellets. Countries in the world, especially Europe, Japan, South Korea, and China, started to use wood pellet as a promising renewable energy source. Indonesia with its tropical climate, the diversity of types of plants and the availability of land area has a chance to be an important producer of this energy source for national or even international demand. One of its province, Special Region (SR) of Yogyakarta, has many community forest groups (CFGs) with high potentiality to support the production of wood pellet. This research aimed to analyze the potential tree species in SR Yogyakarta for wood pellet production. Data were collected through literature review and survey to CFGs at 4 districts: Bantul (22 CFGs), Gunungkidul (15 CFGs), Kulonprogo (16 CFGs), and Sleman (19 CFGs). Dry branch or twigs are the main source of woodfuel for the CFGs. Potential species for wood pellet, Calliandra (Calliandra calothyrsus) and Gliricidia (Gliricidia sepium), were also planted but with different purpose: source of forage, source of nectar for honeybee production, and for soil conservation purpose. Both plant species were planted at the border of community forest lands, among agricultural crops and or among other tree species. There were 0 - 2000 Calliandra/ha and 0 - 3000 Gliricidia/ha planted at those lands. Based on these results it is known that the potential types of plants for the production of wood pellets, Calliandra and
\end{abstract}


Gliricidia, have been planted in SR Yogyakarta. However the planting of both types need to be developed to support a sustainable production of wood pellet.

Key words : calliandra, community forest groups, gliricidia, SR Yogyakarta, wood pellet

\section{PENDAHULUAN}

Negara-negara di dunia mulai beralih ke penggunaan energi terbarukan, terlebih dengan adanya isu perubahan iklim dikarenakan peningkatan gas rumah kaca. Beberapa negara khususnya Eropa, Jepang, Korea Selatan dan China, telah menerapkan peraturan untuk lebih banyak menggunakan sumber energi biomasa, seperti pelet kayu, tidak hanya sumber energi fosil (Goetzl 2015), terlebih setelah pertemuan negara-negara di Paris untuk membahas isu ini. Selain pelet kayu, chip kayu merupakan bentuk lain dari sumber energi biomasa, namun pelet kayu dianggap lebih efektif khususnya untuk pembangkit listrik skala kecil (Pereira et al. 2018).

Energi dari biomasa tanaman, khususnya kayu, dianggap sebagai sumber karbon netral di bumi. Biomasa tanaman yang digunakan dapat bersumber dari hutan. Penggunaan energi ini masih dapat menghasilkan $\mathrm{CO}_{2}$ yang dianggap dapat menyebabkan perubahan iklim. Namun, $\mathrm{CO}_{2}$ tersebut nantinya akan diserap kembali oleh hutan. Karbon netral akan dapat dicapai jika kawasan hutan tersebut dikelola secara berkelanjutan (Amirta 2018). Berbeda dengan energi fosil yang $\mathrm{CO}_{2}$ atau emisi gas lain tidak dapat mengarah ke karbon netral.

Permintaan akan pelet kayu terus meningkat di sebagian negara Eropa dan sebagian negara-negara Asia. Negara penghasil utama pelet kayu di Amerika Utara dan Eropa tidak dapat sepenuhnya berkonsentrasi dalam memenuhi permintaan pasar (Roos 2012; Jonsson \& Rinaldi 2017), sehingga berpeluang bagi negara-negara lain di Asia untuk meningkatkan ekspor mereka (Trømborg et al. 2013). Ekspor pelet kayu Indonesia tercatat telah meningkat sebanyak $165 \%$ dalam kurun waktu 2011-2015 dengan tujuan negara Korea Selatan, Jepang dan Taiwan (Trademap 2016).

Indonesia berpeluang menjadi pengekspor terbesar untuk pelet kayu dibandingkan dengan negara-negara produsen lainnya misalnya Vietnam, Malaysia, China, dan Thailand (ITA 2016). Menurut Goh (2013), jika dilihat dari pasokan kayu, Indonesia memiliki bahan baku yang banyak untuk produksi pelet kayu. Apabila mempertimbangkan luas lahan tanaman, produksi pelet kayu Indonesia dapat lebih tinggi dibandingkan dengan Vietnam, negara dengan ekspor pelet kayu tertinggi di Asia (Sidabutar 2018).

Daerah Istimewa (DI) Yogyakarta merupakan salah satu provinsi di Indonesia yang memiliki hutan rakyat (BPS, 2020). Jenis-jenis tanaman kayu dengan klasifikasi yang sesuai untuk pelet kayu sangat berpeluang untuk dikembangkan. Terlebih, saat ini kemudahan dalam memperoleh legalitas bahan baku kayu dari hutan rakyat telah mendapat dukungan dari pemerintah dengan dikeluarkannya Permen LHK No. P.83/MENHLK/SETJEN/KUM.10/2016 tentang Perhutanan Sosial. Namun, masih diperlukan penelitian tentang jenis-jenis tanaman potensial berikut pola pertanamannya sebagai informasi awal untuk perencanaan pengembangan produksi pelet kayu di DI Yogyakarta. Jenis tanaman yang potensial untuk dikembangkan menjadi bahan baku pelet kayu antara lain kaliandra, gamal, lamtoro dan akasia (Hendrati \& Nurrohmah 2018, 2019; Abdulah 2019; Hendrati et al. 2019). Diantara jenis-jenis tersebut, kaliandra dan gamal dianggap 
yang paling potensial. Penelitian ini bertujuan untuk mengetahui jenis tanaman kayu yang ditanam di DI Yogyakarta, serta jenis potensial dan cara penanaman untuk pengembangan pelet kayu.

\section{METODA PENELITIAN}

\subsection{Tempat dan Waktu}

Penelitian dilaksanakan di DI Yogyakarta. Pada bulan AgustusOktober 2020.

\subsection{Bahan dan Alat}

Alat yang digunakan adalah blangko survey luring maupun daring (google form), alat tulis dan register Kelompok Tani Hutan (KTH) di 4 Kabupaten DI Yogyakarta: Kabupaten Bantul, Gunungkidul, Kulonprogo dan Sleman. Register ini adalah data dari Dinas Lingkungan Hidup dan Kehutanan Provinsi DI Yogyakarta tahun 2020.

Data yang dikumpulkan dari KTH adalah jenis tanaman kayu yang ditanam dan peruntukan utamanya, jenis tanaman kayu yang digunakan sebagai kayu bakar, pemanfaatan utama dan cara penanaman jenis

\section{HASIL PENELITIAN DAN PEMBAHASAN}

Respon yang diperoleh dari 4 kabupaten di DI Yogyakarta berjumlah 22 KTH (Bantul), 15 KTH (Gunungkidul), $15 \mathrm{KTH}$ (Kulonprogo) dan 19 KTH (Sleman). Mayoritas jenis tanaman kayu yang ditanam adalah mahoni (Swietenia macrophylla), jati (Tectona grandis) dan sonokeling (Dalbergia latifolia) dengan tujuan utama pemanfaatan untuk kayu bangunan dan mebel. kaliandra (Calliandra calothyrsus) serta pemanfaatan utama dan cara penanaman jenis gamal (Gliricidia sepium).

\subsection{Rancangan Penelitian}

Penelitian menggunakan metode survey melalui wawancara langsung dan survey daring kepada $497 \mathrm{KTH}$ di DI Yogyakarta yang terdaftar di register.

\subsection{Prosedur Pelaksanaan Penelitian}

Survey dilakukan dengan menghubungi ketua masing-masing KTH untuk kemudian diminta mengisi blangko survey. Wawancara langsung di lokasi juga dilakukan untuk memperjelas atan menambah informasi. KTH yang dimasukkan dalam pendataan adalah KTH yang memiliki lahan sendiri yang ditanami, bukan yang lahannya berupa hutan lindung.

\subsection{Analisis Data}

Data dari setiap KTH yang mewakili kabupaten dikumpulkan dan dianalisis menggunakan analisis statistik deskriptif.

\footnotetext{
Cabang atau ranting kering merupakan jenis bahan yang paling banyak digunakan sebagai kayu bakar oleh KTH di 4 kabupaten di DI Yogyakarta (Tabel 1). Selain itu, jenis mahoni dan jati mendominasi jenis tanaman kayu yang digunakan sebagai kayu bakar. Jenis-jenis potensial untuk kayu energi seperti kaliandra dan gamal juga digunakan walaupun bukan sebagai yang utama. Selain untuk kebutuhan ekspor, jenis-jenis potensial tersebut juga dapat digunakan untuk memenuhi kebutuhan energi di Indonesia (Mahidin et al. 2020).
} 
Tabel 1. Jenis tanaman kayu yang digunakan sebagai kayu bakar oleh KTH di DI Yogyakarta

\begin{tabular}{|c|c|c|}
\hline Kabupaten & Jenis tanaman kayu & Persentase $(\%)^{*}$ \\
\hline \multirow[t]{9}{*}{ Bantul } & Semua cabang dan ranting kering & 68.2 \\
\hline & Mahoni & 45.5 \\
\hline & Jati & 31.8 \\
\hline & Sonokeling & 22.7 \\
\hline & Besiah/sengon laut & 13.6 \\
\hline & Sampah laut & 9.1 \\
\hline & Duwet & 4.5 \\
\hline & Gamal & 4.5 \\
\hline & Kaliandra & 4.5 \\
\hline \multirow[t]{9}{*}{ Gunungkidul } & Semua cabang dan ranting kering & 60.0 \\
\hline & Jati & 53.3 \\
\hline & Mahoni & 53.3 \\
\hline & Duwet & 33.3 \\
\hline & Besiah/sengon laut & 20.0 \\
\hline & Gamal & 20.0 \\
\hline & Johar & 20.0 \\
\hline & Mindi & 20.0 \\
\hline & Akasia & 13.3 \\
\hline \multirow[t]{8}{*}{ Kulonprogo } & Semua cabang dan ranting kering & 100.0 \\
\hline & Mahoni & 20.0 \\
\hline & Sampah kayu laut & 13.3 \\
\hline & Sonokeling & 13.3 \\
\hline & Jati & 13.3 \\
\hline & Besiah/sengon laut & 13.3 \\
\hline & Kaliandra & 13.3 \\
\hline & Gamal & 13.3 \\
\hline \multirow[t]{9}{*}{ Sleman } & Semua cabang dan ranting kering & 57.9 \\
\hline & Mahoni & 21.1 \\
\hline & Sonokeling & 15.8 \\
\hline & Kaliandra & 10.5 \\
\hline & Jati & 10.5 \\
\hline & Johar & 10.5 \\
\hline & Mindi & 10.5 \\
\hline & Besiah/sengon laut & 5.3 \\
\hline & Duwet & 5.3 \\
\hline
\end{tabular}

Jenis kaliandra tidak selalu ditanam oleh KTH di 4 kabupaten di DI Yogyakarta (Tabel 2). Pemanfaatan utama di 4 kabupaten tersebut adalah sebagai sumber Hijauan Makanan Ternak (HMT). Selain itu kaliandra digunakan sebagai sumber nectar untuk lebah madu dan kayu bakar. Jumlah KTH di Kulonprogo yang tidak menanam jenis ini lebih sedikit apabila dibandingkan dengan jumlah KTH di kabupaten lain. Jumlah kaliandra yang ditanam berkisar antara $0-2000$ pohon kaliandra per ha. 
Jenis kaliandra adalah salah satu jenis dari famili Leguminoceae yang sudah banyak digunakan sebagai sumber HMT. Jenis ini juga terbukti dapat meningkatkan deposisi nutrient kambing (Cakra et al. 2016) dan juga produktivitas domba (Nurjannah et al. 2019).
Sosialisasi penggunaan jenis ini sebagai kayu energi di Kulonprogo sudah pernah dilakukan oleh Prasetyo et al. (2018). Rahayu et al. (2020) menjelaskan bahwa kualitas pelet kayu dari jenis kaliandra lebih baik dibandingkan dari gamal atau dari sisa-sisa gergajian kayu.

Tabel 2. Pemanfaatan utama jenis kaliandra oleh KTH di DI Yogyakarta

\begin{tabular}{llr}
\hline Kabupaten & Pemanfaatan utama jenis kaliandra & Persentase $(\%) *$ \\
\hline \multirow{2}{*}{ Bantul } & Tidak menanam & 59.1 \\
& HMT & 22.7 \\
& Nektar lebah & 9.1 \\
& Kayu bakar & 4.5 \\
& Konversi alam & 4.5 \\
\hline \multirow{2}{*}{ Gunungkidul } & Tidak menanam & 60.0 \\
& HMT & 26.7 \\
& Nektar lebah & 6.7 \\
& Konversi alam & 6.7 \\
\hline \multirow{2}{*}{ Kulonprogo } & HMT & 53.3 \\
& Tidak menanam & 26.7 \\
& Konversi alam & 13.3 \\
& Nektar lebah & 6.7 \\
\hline \multirow{2}{*}{ Sleman } & Tidak menanam & 57.9 \\
& HMT & 31.6 \\
& Nektar lebah & 5.3 \\
& Konversi alam & 5.3 \\
\hline *Persentase: (jumlah KTH yang menggunakan/ jumlah KTH total) $x ~ 100$
\end{tabular}

Jenis kaliandra umumnya ditanam di pinggir lahan oleh KTH di DI Yogyakarta (Tabel 3). Beberapa KTH juga menanam jenis tersebut di antara tanaman pertanian, di antar tanaman pohon dan di pinggir pantai. 
Tabel 3. Cara penanaman jenis kaliandra oleh KTH di DI Yogyakarta

\begin{tabular}{llr}
\hline Kabupaten & Cara penanaman jenis kaliandra & Persentase (\%)* \\
\hline \multirow{2}{*}{ Bantul } & Tidak menanam & 59.1 \\
& Di pinggir lahan & 36.4 \\
& Diantara tanaman pertanian & 9.1 \\
\hline \multirow{2}{*}{ Gunungkidul } & Tidak menanam & 60.0 \\
& Di pinggir lahan & 33.3 \\
& Diantara tanaman pertanian & 6.7 \\
& Diantara tanaman pohon & 6.7 \\
\hline \multirow{2}{*}{ Kulonprogo } & Di pinggir lahan & 53.3 \\
& Diantara tanaman pertanian & 26.7 \\
& Tidak menanam & 26.7 \\
& Diantara tanaman pohon & 6.7 \\
& Di pinggir pantai & 6.7 \\
\hline Sleman & Tidak menanam & 57.9 \\
& Di pinggir lahan & 36.8 \\
& Diantara tanaman pohon & 15.8 \\
& Diantara tanaman pertanian & 5.3 \\
\hline *Persentase: (jumlah KTH yang menggunakan/ jumlah KTH total) x 100
\end{tabular}

Jenis gamal tidak selalu ditanam oleh KTH di 4 kabupaten di DI Yogyakarta (Tabel 4). Pemanfaatan utama di 4 kabupaten tersebut adalah sebagai sumber HMT. Selain itu gamal juga digunakan sebagai kayu bakar, penguat tanah dan untuk menjalarkan tanaman merambat. Jumlah KTH di Kulonprogo dan Sleman yang tidak menanam jenis ini lebih sedikit apabila dibandingkan dengan jumlah KTH di kabupaten lain. Jumlah gamal yang ditanam berkisar antara $0-3000$ pohon gamal per ha.
Jenis lain dari famili Leguminoceae yang digunakan sebagai HMT adalah gamal. Jenis ini terbukti dapat meningkatkan volatile fatty acids (VFA) pada kerbau (Nuswantara 2009). Selain itu jenis ini tidak mengandung tannin yang dapat menghambat pencernaan ternak (Mariyono et al. 1998), terlebih apabila dibandingkan dengan jenis kaliandra yang terbukti memiliki lebih banyak tannin (Whetton et al. 1997). Namun, berdasarkan Daning \& Foekh (2018), kualitas nutrisi daun dan kulit kayu gamal dan kaliandra tidak berbeda nyata untuk digunakan sebagai HMT.

Tabel 4. Pemanfaatan utama jenis gamal oleh KTH di DI Yogyakarta

\begin{tabular}{llr}
\hline Kabupaten & $\begin{array}{l}\text { Pemanfaatan utama jenis } \\
\text { gamal }\end{array}$ & $\begin{array}{r}\text { Persentase } \\
(\boldsymbol{\%})^{*}\end{array}$ \\
\hline Bantul & Tidak menanam & 54.5 \\
& HMT & 22.7 \\
& Kayu bakar & 18.2
\end{tabular}




\begin{tabular}{llr} 
& Penguat tanah & 13.6 \\
\hline Gunungkidul & Tidak menanam & 53.3 \\
& HMT & 40.0 \\
& Penguat tanah & 6.7 \\
& Kayu bakar & 6.7 \\
\hline Kulonprogo & HMT & 53.3 \\
& Tidak menanam & 33.3 \\
& Kayu bakar & 20.0 \\
& Menjalarkan tanaman yang & 13.3 \\
& merambat & 52.6 \\
\hline Sleman & HMT & 31.6 \\
& Tidak menanam & 10.5 \\
& Kayu bakar & 10.5 \\
\hline Penguat tanah &
\end{tabular}

Jenis gamal umumnya ditanam di pinggir lahan oleh KTH di DI Yogyakarta (Tabel 5). Beberapa KTH juga menanam jenis tersebut di antara tanaman pertanian dan pohon.

Tabel 5. Cara penanaman jenis gamal oleh KTH di DI Yogyakarta

\begin{tabular}{llr}
\hline Kabupaten & Cara penanaman jenis gamal & $\begin{array}{r}\text { Persentase } \\
(\boldsymbol{\%})\end{array}$ \\
\hline Bantul & Tidak menanam & 54.5 \\
& Di pinggir lahan & 36.4 \\
& Diantara tanaman pertanian & 4.5 \\
& Diantara tanaman pohon & 4.5 \\
\hline Gunungkidul & Tidak menanam & 53.3 \\
& Di pinggir lahan & 46.7 \\
& Diantara tanaman pohon & 6.7 \\
\hline Kulonprogo & Di pinggir lahan & 53.3 \\
& Tidak menanam & 33.3 \\
& Diantara tanaman pertanian & 20.0 \\
\hline Sleman & Di pinggir lahan & 42.1 \\
& Tidak menanam & 31.6 \\
& Diantara tanaman pohon & 21.1 \\
& Diantara tanaman pertanian & 5.3 \\
\hline Persentase: (jumlah KTH yang menggunakan/ jumlah KTH total) & X 100
\end{tabular}

\section{KESIMPULAN}

Jenis potensial sumber kayu energi yaitu kaliandra dan gamal, sudah ditanam oleh KTH di DI Yogyakarta walaupun bukan merupakan tanaman utama dan pemanfaatan utamanya bukan sebagai kayu energi. Pengembangan penanaman kedua jenis ini perlu dilakukan untuk mendukung produksi kayu energi sebagai salah satu jenis energi terbarukan. 
Studi lanjut seperti Life Cycle Analysis perlu dilakukan untuk mendukung efisiensi produksi pelet kayu dari hulu ke hilir (Laschi et al. 2016). Tahap-tahap alternatif dan faktor-faktor yang berpengaruh dalam proses produksi juga perlu dipertimbangkan untuk memperoleh pelet kayu dengan kualitas yang baik (Uasuf \& Becker 2011; Jackson et al. 2016).

\section{UCAPAN TERIMA KASIH}

Penulis mengucapkan terima kasih kepada Sekolah Vokasi, Universitas Gadjah Mada yang telah menyediakan pendanaan bagi penelitian ini. Penulis juga mengucapkan terima kasih kepada Dinas Lingkungan Hidup dan Kehutanan DI Yogyakarta atas informasi yang diberikan tentang Kelompok Tani Hutan di wilayah DI Yogyakarta.

\section{DAFTAR PUSTAKA}

Abdulah, L. (2019). The growth and yield of Calliandra callothyrsus trees as biomass-based energy feedstock. IOP Conf. Series: Earth and Environmental Science 308: 012078

Amirta, R. (2018). Pelet kayu energi hijau masa depan. Mulawarman University Press. Samarinda

Badan Pusat Statistik. (2020). Provinsi Daerah Istimewa Yogyakarta Dalam Angka 2020. BPS Provinsi DI Yogyakarta. Yogyakarta

Cakra, I.G.L.O., \& Trisnadewi, A.A.A.S. (2016). Penggantian daun gamal (Gliricidia sepium) dengan kaliandra (Calliandra callothyrsus) dalam ransum kambing terhadap kadar urea darah dan deposisi nutrient. Majalah Ilmiah Peternakan 19(3): 110-114.

Daning, D.R.A., \& Foekh, B. (2018). Evaluasi produksi dan kualitas nutrisi pada bagian daun dan kulit kayu Calliandra callotirsus dan Gliricidia sepium. Sains Peternakan 16(1): 7-11

Darmawan, U.W. (2012). Pengembangan Kaliandra (Calliandra callothyrsus) sebagai kayu energi. Mitra Hutan Tanaman 7(2): 39-50

Goetzl, A. (2015). Developments in theglobal trade of wood pelets. Office of Industries, US International Trade Commission, Office of Industries Working Paper-US International Trade Commission.

Goh, C.S., \& Junginger, M. (2013). Low cost, long distance biomass supply chains. IEA Bioenergi Task 40: Sustainable international bioenergi trade.

Hendrati, R.L., \& Nurrohmah, S.H. (2018). Quality of geneticallyimproved Acacia auriculiformis for renewable short-rotation woodenergy. Jurnal Manajemen Hutan Tropika 24(3): 136-143

Hendrati, R.L., \& Nurrohmah, S.H. (2019). Genetic improvement of Leucaena leucocephala for wood energy. Tropical GrasslandsForrajes Tropicales 7(2): 210-213

Hendrati, R.L., Hidayati, N., \& Nurrohmah, S.H. (2019). Biomass and coppicing ability of genetically improved Calliandra calothyrsus for wood-energy with different spacing. IOP Conf. Series: Earth and Environmental Science 522: 012001

International Trade Administration, Departement of Commerce United 
States of America. (2016). 2016 Top market reports renewable fuels, sector snapshot. biomass wood pelets. http://trade.gov/topmarkets/pdf/Ren ewable_Fuels_Biomass_Wood_Pel ets.pdf

Jackson, J., Turner, A., Mark, T., \& Montross, M. (2016). Densification of biomass using a pilot scale flat ring roller pellet mill. Fuel Processing Technology 148: 43-49

Jonsson, R., \& Rinaldi, F. (2017). The impact on global wood-product markets of increasing consumption of wood pellets within the European Union. Energy 133: 864-878

Laschi, A., Marchi, E., \& GonzálezGarcía, S. (2016). Environmental performance of wood pellets' production through life cycle analysis. Energy 103: 469-480

Mahidin, Erdiwansyah, Zaki, M., Hamdani, Muhibbuddin, Hisbullah, Mamat, R., \& Susanto, H. (2020). Potential and utilization of biomass for heat energy in Indonesia: a review. International Journal of Scientific \& Technology Research 9(10): 331-344

Mariyono, U., Umiyasih, B., Tangendjaja, Musofie, A., \& Wardhani, N.K. (1998). Pemanfaatan leguminosa yang mengandung tannin sebagai pakan sapi perah dara. Pros. Sem. Nas. II. INMT: 171-172

Nurjannah, S., Ayuningsih, B., Hernaman, I., \& Susilawati, I. (2019). Penggunaan Kaliandra (Calliandra callothyrsus), Indigofera sp., dan campurannya dalam ransum sebagai pengganti konsentrat terhadap produktivitas domba garut jantan. Jurnal Ilmiah Peternakan Terpadu 7(3): 293-298
Nuswantara, L.K. (2009). Parameter fermentasi rumen pada kerbau yang diberi pakan tunggal glirisidia, jerami jagung dan kaliandra. Prosiding Seminar Nasional Kebangkitan Peternakan: 244-252

Pereira, M.F., Nicolau, V.P., \& Bazzo, E. (2018). Exergoenvironmental analysis concerning the wood chips and wood pellets production chains. Biomass and Bioenergy 119:253-262

Prasetyo, E., Wiyono, Lestari, P., Hidayat, R., Oktalina, S.N., Ngadianto, A., \& Nugroho, P. (2018). Penanaman kaliandra sebagai kayu energi dan hijauan makanan ternak pada pertanaman agroforestry masyarakat Desa Gerbosari, Samigaluh Kulon Progo. Jurnal Pengabdian dan Pengembangan Masyarakat 1(1): 110

Rahayu, S., Hilyana, S., Suryani, E., Sari, N.H., \& Ali, M. (2020). Analysis of wood pellet quality fron Calliandra callothyrsus, Gliricidia sepium, and sawdust as new and renewable energy. Proceedings International Conference on Science and Technology 1: 110-115

Roos, A. (2012). The Asian wood pelet markets, United States Department of Agriculture, Forest Service, Pacific Northwest Research Station, General Technical Report PNWGTR-861

Sidabutar, V.T.P. (2018). Kajian peningkatan potensi ekspor pelet kayu Indonesia sebagai sumber energi biomasa yang terbarukan. Jurnal Ilmu Kehutanan 12: 99-116

Trademap. 2016. Perdagangan bilateral Indonesia - dunia dengan HS Code 270111, 270112, 270119 dan 
440131.

http://trademap.org/Country_SelPro ductCountry_TS.aspx?nvpm=1|360| ||270111||6|1|1|2|2|1|2|1|1

Trømborg, E., Ranta, T., Schweinle, J., Solberg, B., Skjevrak, G., \& Tiffany, D.G. (2013). Economic sustainability for wood pellets production - A comparative study between Finland, Germany, Norway, Sweden and the US. Biomass and Bioenergy 57: 68-77

Uasuf, A., \& Becker, G. (2011). Wood pellets production costs and energy consumption under different framework conditions in Northeast Argentina. Biomass and Bioenergy 35: $1357-1366$
Whetton, M., Rosslter, J.T., \& Wood, C.D. (1997). Nutritive evaluation of nitrogenous fractions in leaves of Gliricidia sepium and Caliandra calothyrsus in relation to tannin content and protein degradation by rumen microbes in vitro. J. Agric. Food Chem. 45: 3570-3576 